\title{
Ekstraksi Xilan dan Delignifikasi Bagas (Limbah Pabrik Gula)
}

\author{
Gading Wilda Aniriani ${ }^{1}$
}

Email : gading.wildaa@gmail.com

1) Dosen Program S1 Studi Ilmu Lingkungan Fakultas Teknik Universitas Islam Lamongan

\begin{abstract}
Abstrak
Limbah ampas tebu (bagas) pabrik gula biasanya digunakan sebagai bahan bakar (ketel) dalam proses pemanasan, sisanya sengaja ditiimbun dan membusuk sehingga mengeluarkan air lindi (seperti molase) yang berbau tidak sedap. Pemanfaatan untuk pakan ternak maupun pupuk kompos memang masih dinilai memiliki nilai ekonomi yang kecil. Oleh karena itu dibutuhkan pengolahan yang memiliki nilai produk jual yang tinggi dan teknologi yang tepat guna. Teknologi yang dapat mengurangi volume limbah untuk dimanfaatkan sebagai bahan dasar industri lain merupakan sebuah sistem ekoindustri. Bagas tergolong jenis limbah lignuselulosa, dimana kandungan selulosa secara alami diikat oleh hemiselulosa (xilan) dan dilindungi oleh lignin, oleh karena itu disebut dengan lignoselulosa. Penelitian ini bertujuan untuk melakukan pretreatmen bagas dengan menghilangkan lignin dan mengekstraksi xilan. Produk yang dihasilkan merupakan jenis polisakarida, dimana dapat dimanfaatkan sebagai substrat enzim untuk proses pembuatan bioetanol, prebiotik, probiotik dan lain sebagainya. Proses pretreatmen bagas meliputi delignifikasi menggunakan sodium hipoklorit $(\mathrm{NaOCl}) 1 \%$ dan ekstraksi xilan menggunakan metode alkalin $(\mathrm{NaOH} 15 \%)$ sebagai pelarut. Hasil ekstraksi xilan dari bagas diperoleh 9,9\% xilan dari bagas dan setelah pemurnian diperoleh $3,4 \%$ xilan larut. Setiap melalui tahapan pretreatment terjadi pengurangan berat bagas dari $1000 \mathrm{~g}$ menjadi $34 \mathrm{~g}$ pada akhir pemurnian xilan. Rendemen bagas hasil delignifikasi sebanyak 704,74 g (29,74\%), dengan rendemen ekstraksi sebanyak 98,80 g xilan (9,9\%) dan setelah purifikasi didapatkan $3,4 \%$ xilan murni.
\end{abstract}

Kata kunci: bagas, delignifikasi, ekstraksi, xilan, ekoindustri.

\section{PENDAHULUAN}

Ampas tebu atau bagasse (bagas) merupakan limbah yang dihasilkan dari proses awal pembuatan gula. Tebu sendiri merupakan jenis tanaman lignuselulosa, karena memiliki komponen lignin dan selulosa. Menurut Lavarack et al. (2002) bagas merupakan hasil samping proses pembuatan gula tebu (sugarcane) yang mengandung residu berupa serat. Minimal $50 \%$ serat bagas diperlukan sebagai bahan bakar (ketel) sedangkan $50 \%$ sisanya hanya ditimbun sebagai buangan yang memiliki nilai ekonomi rendah. Serat bagas umumnya mengandung polisakarida yang tersusun atas 50\%-55\% selulosa, 15\%-20\% hemiselulosa dan lignin sekitar 20-30\%, selain itu sisanya disebut senyawa abu (Pandey et al. 2000; Samsuri et al. 2009). Beberapa contoh bahan lignoselulosa diantaranya adalah limbah-limbah pertanian (rumput, alang-alang, sekam padi, jerami, batang gandum, tongkol jagung) dan limbah-limbah hasil samping industri fermentasi (molase, bagas) (Iranmahboob et al. 2002; Campo et al. 2006). Sandra et al. (2007) menambahkan bahwa komponen kimia dari ampas tebu secara rinci meliputi 37,35\% glukan (selulosa), 23,66\% xilan (hemiselulosa), 2,1\% lignin, 3,25\% senyawa ekstraktif lain, dan $1,79 \%$ senyawa abu. Selulosa secara alami diikat oleh hemiselulosa dan dilindungi oleh lignin, oleh karena itu disebut dengan lignoselulosa.

Penanganan limbah ini menjadi masalah yang belum terselesaikan bagi beberapa pabrik gula dalam mengelola limbah ampas tersebut. Selain digunakan sebagai ketel dalam proses pemanasan gula, sisanya sengaja ditiimbun dan membusuk sehingga mengeluarkan air lindi (seperti molase) yang berbau tidak sedap. Hal tersebut dapat menyebabkan terjadinya proses bakterisasi dalam air lindi sehingga memunculkan gas-gas yang ketika tersulut api maka akan terbakar. Tentunya kejadian tersebut dapat merugikan pabrik gula, karena berpotensi terjadinya kebakaran. Sedangkan pemanfaatan sederhana dari ampas tebu adalah sebagai campuran pakan ternak dan pupuk kompos, namun hal ini sangat jarang terealisasi tanpa adanya pihak atau divisi yang khusus menangani ini dalam sebuah pabrik. Pemanfaatan untuk pakan ternak maupun pupuk kompos memang masih dinilai 
memiliki nilai ekonomi yang kecil. Oleh karena itu dibutuhkan pengolahan yang memiliki nilai ekonomis yang tinggi dan memiliki nilai produk jual yang tinggi dan teknologi yang tepat guna. Teknologi yang dapat mengurangi volume limbah untuk dimanfaatkan sebagai bahan dasar industri lain merupakan sebuah sistem ekoindustri.

Sistem ekoindustri merupakan produksi yang lebih bersih (cleaner production) atau ekologi industri, untuk mencapai keberlanjutan (sustainability) pembangunan, industri dan lingkungan maka diperlukan revolusi ekoindustri. Proses industri harus diintegrasikan sebagai suatu sistem tertutup aliran materi, yaitu suatu jaringan dimana limbah dari satu industri menjadi bahan baku industri lainnya, dan industri wajib mengambil kembali kemasan atau produk bekasnya. Penelitian ini bertujuan untuk mengolah limbah bagas dari pabrik gula untuk di produksi kembali menjadi bahan dasar untuk produksi industri lain, misalnya industri bioetanol, prebiotik, probiotik dan lain sebagainya.

\section{METODOLOGI PENELITIAN}

Bagas diperoleh dari limbah ampas tebu. Bahan-bahan lain yang digunakan dalam proses pretreatmen terdiri atas $\mathrm{NaOCl}, \mathrm{NaOH}, \mathrm{HCl} 37 \%$, Etanol $95 \%$, akuades, $\mathrm{HCl}$, dan larutan asam sulfat pekat $\left(\mathrm{H}_{2} \mathrm{SO}_{4}\right.$ pekat). Berikut adalah prosedur penelitian yang dilakukan.

\section{Preparasi Bagas}

Limbah tebu yang berupa ampas tebu di keringkan dengan oven pada suhu $80{ }^{\circ} \mathrm{C}$ sampai kering dan dihancurkan dengan mesing giling. Setelah menjadi serbuk bagas kemudian dilakukan pembubukan lolos saringan 40 mesh, hasil modifikasi dari Lee (2003). Kandungan total selulosa, hemiselulosa, lignin dan lain-lain pada bagas didapatkan dari analisis proksimat dan komponen serat.

\section{Delignifikasi}

Delignifikasi serbuk bagas dilakukan berdasarkan penelitian Richana et al. (2007) (yang telah dimodifikasi) dengan menggunakan pelarut natrium hipoklorit $(\mathrm{NaOCl}) 1 \%$, proses delignifikasi dilakukan selama 5 jam pada suhu ruang. Hasilnya kemudian dicuci sampai bau $\mathrm{NaOCl}$ nya hilang, lalu dilakukan proses penyaringan untuk membuang air yang mengandung lignin. Bubuk bagas kemudian dikeringkan pada suhu $50{ }^{\circ} \mathrm{C}$ selama 48 jam. Hasil delignifikasi dianalisis proksimat dan komponen serat kembali untuk mendapatkan kandungan selulosa, hemiselulosa dan lignin setelah delignifikasi.

\section{Ekstraksi Xilan dari Bagas}

Metode ekstraksi xilan menggunakan metode dari Richana et al. (2007). Ekstraksi xilan menggunakan $\mathrm{NaOH}$ sebagai larutan pengekstrak xilan dari bagas, karena sifat kelarutannya pada xilan (Tabel 1). Padatan hasil delignifikasi direndam dalam larutan natrium hidroksida $(\mathrm{NaOH}) 15 \%$ pada suhu $28^{\circ} \mathrm{C}$ selama 24 jam untuk mendapatkan ekstrak xilan. Setelah 24 jam dilakukan penyaringan dengan menggunakan kain saring, filtrat (suspensi) yang dihasilkan dari proses ekstraksi diukur $\mathrm{pH}$ nya kemudian dinetralkan dengan menggunakan $\mathrm{HCl} 37 \%$ sampai netral ( $\mathrm{pH}$ 7). Suspensi kemudian di sentrifuge pada $6000 \mathrm{~g}$ selama 15 menit. Supernatan mengandung ekstrak xilan, sedangkan endapan dibuang. Xilan yang larut dalam supernatan dibersihkan dengan menambahkan etanol 95\%. Etanol ditambahkan pada supernatan dengan perbandingan supernatan-etanol ialah 1:3 kemudian dilakukan sentrifuge kembali dengan kecepatan 6000 g selama 15 menit. Hasil dari sentrifugasi tersebut ialah endapan yang mengandung xilan.

Tabel 1 Kelarutan xilan dalam beberapa pelarut ${ }^{\mathrm{a}}$

\begin{tabular}{lc}
\hline \multicolumn{1}{c}{ Pelarut } & Kelarutan \\
\hline $\mathrm{NaOH} 1 \%$ & +++ (sangat larut) \\
Air Panas $\left(90^{\circ} \mathrm{C}\right)$ & ++ (larut) \\
Air Dingin $\left(27^{\circ} \mathrm{C}\right)$ & + (sedikit larut) \\
$\mathrm{HCl} \mathrm{1N}$ & - (tidak larut)
\end{tabular}

a Sumber: Richana et al. (2007).

Hasil ekstraksi xilan kemudian dimurnikan dengan $\mathrm{NaOH} 4 \%$. Xilan larut didapatkan dari endapan yang sudah dikeringkan pada suhu $50{ }^{\circ} \mathrm{C}$ selama 72 jam. Pemurnian ini bertujuan untuk menghilangkan komponen polisakarida lain yang masih tersisa di dalam xilan.

\section{Penentuan Kemampuan Delignifikasi Substrat}

Substrat hasil delignifikasi dengan $\mathrm{NaOCl}$ $1 \%$ yang telah dikeringkan dalam oven $5{ }^{\circ} \mathrm{C}$ selama 48 jam. Substrat ini selanjutnya digunakan untuk analisis kandungan selulosa, hemiselulosa dan lignin menggunakan metode Van Soest et al. (1991). Persentase kehilangan bobot substrat dihitung dengan persamaan berikut: 
$\begin{aligned} & \text { Susut } \\ & \text { BKO harike 0-BKO hariket }\end{aligned} \quad(\%)=$ $\frac{\text { BKO hari ke 0-BKO hari ket }}{\text { BKO hari ke0 }} \times 100 \%$

Keterangan :

$\mathrm{BKO}=$ Bobot Kering Oven $(\mathrm{g})$

Penurunan kadar komponen serat (sebagai lignin, selulosa, hemiselulosa) dihitung berdasarkan rumus:

- $\quad$ Persentase penurunan komponen serat $(\%)=$ $x-\left[y\left(\frac{100-z}{100}\right)\right]$

Keterangan :

$\mathrm{x}=$ kadar komponen serat sebelum delignifikasi $(\%)$

$\mathrm{y}=$ kadar kompnen serat setelah delignifikasi $(\%)$

$\mathrm{z}=$ susut bobot $(\%)$

\section{HASIL DAN PEMBAHASAN}

Limbah bagas didapatkan dari beberapa tempat yang berbeda, yakni berasal dari limbah pabrik gula. Proses pretreatment bagas membutuhkan sebanyak $1000 \mathrm{~g}$ serbuk bagas kering. Berikut ialah proses preparasi bagas secara bertahap sebelum dilakukan pretreatment yang disajikan dalam Gambar 1.
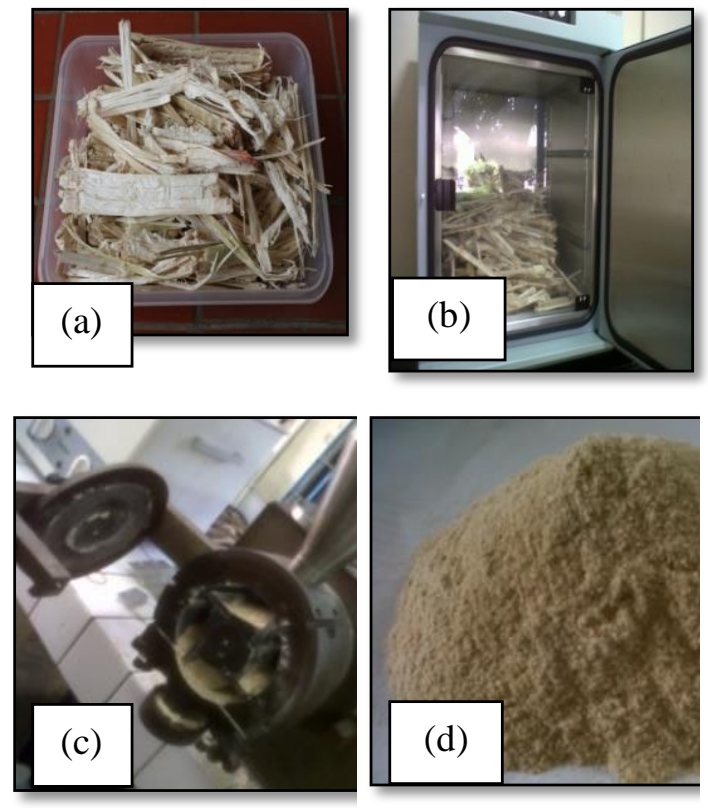

Gambar 1 Preparasi bagas secara fisik. Limbah ampas tebu (bagas) basah (a), pengeringan pada suhu $80{ }^{\circ} \mathrm{C}$ selama \pm 24 jam sampai kering (b), penggilingan (c), bagas lolos mesh 40 (d)
Setiap melalui tahapan pretreatment terjadi pengurangan berat bagas dari $1000 \mathrm{~g}$ menjadi $34 \mathrm{~g}$ pada akhir pemurnian xilan. Rendemen bagas hasil delignifikasi sebanyak 704,74 g (29,74 \%), dengan rendemen ekstraksi sebanyak 98,80 g xilan $(9,9 \%)$ dan setelah purifikasi didapatkan $3,4 \%$ xilan murni (Tabel 1). Hasil serupa juga telah didapatkan dalam penelitian Richana et al. (1994), bahwa xilan hasil ekstraksi dari bagas tebu mencapai 9,6\% tanpa pemurnian.

Tabel 2 Hasil dari neraca massa tahapan pretreatment bagas tebu

\begin{tabular}{ccc}
\hline \multirow{2}{*}{$\begin{array}{c}\text { Tahap } \\
\text { Perlakuan }\end{array}$} & Berat $(\mathrm{g})$ & $\begin{array}{c}\text { Penurunan } \\
\text { Persentase } \\
(\%)\end{array}$ \\
\cline { 2 - 3 } & 1000 & 100 \\
\hline Bagas & 704,74 & 29,52 \\
\hline Delignifikasi & 98,8 & 9,9 \\
\hline Ekstraksi xilan & 34 & 3,4 \\
\hline Pemurnian xilan & & \\
\hline
\end{tabular}

Penurunan terjadi karena hilangnya material selama proses penyaringan (Tabel 2), komponen lignin maupun polisakarida yang terlarut di dalam pelarut. Berdasarkan studi yang sama Fengel dan Wegener (1995) menyimpulkan bahwa ekstraksi pada jenis kayu lunak menggunakan larutan $\mathrm{NaOH}$ menghasilkan xilan antara 5\% - 17,5\%. Semakin tinggi konsentrasi yang digunakan maka semakin tinggi pula tingkat kelarutan xilan. Bagian yang larut dalam media alkali tetapi dapat mengendap dari larutan yang dinetralkan disebut $\beta$-selulosa dan untuk selulosa yang tidak larut dalam larutan $\mathrm{NaOH}$ kuat ialah jenis $\alpha$-selulosa (Fengel dan Wegener 1995). Selain melakukan pemisahan secara mekanik yakni sentrifugasi, suspensi hasil ekstraksi masih perlu difraksinasi untuk memisahkan hemiselulosa xilan dari fraksi pengotor seperti $\alpha$-selulosa dan $\beta$ selulosa. Sebanyak $50 \mathrm{~g}$ bagas kombinasi perbandingan $\mathrm{NaOCl} 0,5 \%$ dan etanol:supernatan (1:3) menghasilkan rendemen xilan tertinggi sebesar 12,95\% (Richana et al. 2007). Perbedaan hasil rendemen xilan dalam penelitian tersebut diduga karena perbedaan biomassa dan perbedaan jumlah bagas yang digunakan terlalu banyak (1000 g), sehingga proses pengikatan xilan kurang merata dan dibutuhkan waktu perendaman yang lebih lama. 
Tabel 2 Perbandingan komponen hemiselulosa, selulosa dan lignin sebelum dan sesudah delignifikasi (\%), hasil uji proksimat.

\begin{tabular}{lcccc}
\hline $\begin{array}{l}\text { Keteran } \\
\text { gan }\end{array}$ & \multicolumn{4}{c}{ Jumlah (\%) } \\
\cline { 2 - 5 } & $\begin{array}{c}\text { Hemiselu } \\
\text { losa } \\
\text { (xilan) }\end{array}$ & $\begin{array}{c}\text { Selulos } \\
\text { a }\end{array}$ & Lignin & $\begin{array}{c}\text { Bahan } \\
\text { ekstrak } \\
\text { tif lain }\end{array}$ \\
\hline $\begin{array}{l}\text { Bagas } \\
\text { Raw }\end{array}$ & 11,54 & 53,29 & 24,19 & 10,98 \\
\hline $\begin{array}{l}\text { Bagas } \\
\text { terdelig } \\
\text { nifikasi }\end{array}$ & 23,97 & 39,42 & 12,62 & 23,99 \\
\hline
\end{tabular}
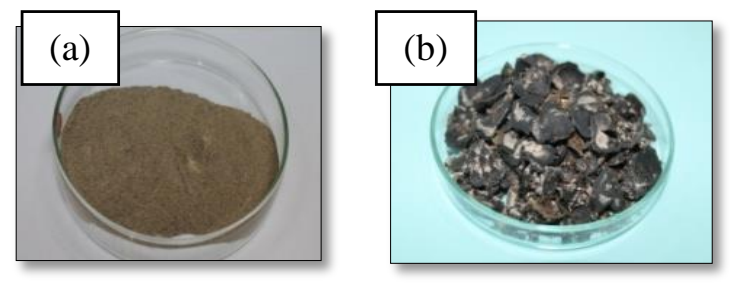

Gambar 2 Ekstraksi bagas menggunakan metode alkali. (a) xilan murni setelah dihaluskan dan diayak lolos mesh 40 dan (b) hasil ekstraksi xilan 40.

Xilan atau hemiselulosa berada diantara lignin dan kumpulan serat selulosa. Lapisan xilan berikatan secara kovalen dengan lignin dan nonkovalen dengan selulosa melalui ikatan hidrogen (Beg et al. 2001). Apabila delignifikasi dapat mengurangi jumlah lignin, maka secara otomatis ikatan xilan dengan selulosa akan mudah terputus. Pemecahan rantai polisakarida tersebut dengan lignin akan memberikan peningkatan jumlah hemiselulosa yang dihasilkan. Fengel dan Wegener (1995) menyatakan bahwa untuk mendapatkan produk hemiselulosa, dalam proses delignifikasi terjadi kehilangan selulosa yang diakibatkan oleh degradasi oksidatif maupun hidrolitik. Penurunan jumlah selulosa maupun lignin dikarenakan terlarut di dalam $\mathrm{NaOCl}$, sedangkan polisakarida yang mengendap adalah xilan. kehilangan selulosa terjadi kemungkinan karena terlarut sebagai kompleks ligninpolisakarida.

Penurunan terjadi karena hilangnya material selama proses penyaringan, komponen lignin maupun polisakarida yang terlarut di dalam pelarut. Berdasarkan studi yang sama Fengel dan Wegener (1995) menyimpulkan bahwa ekstraksi pada jenis kayu lunak menggunakan larutan $\mathrm{NaOH}$ menghasilkan xilan antara 5\%-17,5\%. Semakin tinggi konsentrasi yang digunakan maka semakin tinggi pula tingkat kelarutan xilan. Bagian yang larut dalam media alkali tetapi dapat mengendap dari larutan yang dinetralkan disebut $\beta$-selulosa dan untuk selulosa yang tidak larut dalam larutan $\mathrm{NaOH}$ kuat ialah jenis $\alpha$-selulosa (Fengel dan Wegener 1995). Selain melakukan pemisahan secara mekanik yakni sentrifugasi, suspensi hasil ekstraksi masih perlu difraksinasi untuk memisahkan hemiselulosa xilan dari fraksi pengotor seperti $\alpha$-selulosa dan $\beta$-selulosa. Sebanyak $50 \mathrm{~g}$ bagas kombinasi perbandingan $\mathrm{NaOCl} \quad 0,5 \%$ dan etanol:supernatan (1:3) menghasilkan rendemen xilan tertinggi sebesar 12,95 \% (Richanaet al. 2007). Perbedaan hasil rendemen xilan dalam penelitian tersebut diduga karena perbedaan biomassa dan perbedaan jumlah bagas yang digunakan terlalu banyak (1000 g), sehingga proses pengikatan xilan kurang merata dan dibutuhkan waktu perendaman yang lebih lama.

Pemurnian hasil ekstraksi xilan menjadi penting karena masih terdapatnya komponenkomponen pengotor lain, seperti selulosa dan lignin. $\gamma$-selulosa ialah nama untuk bagian yang tetap larut meskipun dalam larutan yang dinetralkan (Cross dan Bevan 1912; Fengel dan Wegener 1995). Selama ekstraksi dengan larutan alkali kuat, maka bagian selulosa yang memiliki berat molekul rendah dapat terlarut bersama-sama dengan hemiselulosa.

Analisis komponen kimia menggunakan uji proksimat dan analisis komponen serat. Hasil analisis komponen kimia terhadap bagas disajikan pada Tabel 3.

Tabel 3 Komposisi kimia hasil analisis komponen proksimat bagas sebelum dan setelah delignifikasi.

\begin{tabular}{lccccc}
\hline & \multicolumn{4}{c}{ Hasil analisis (\%) } \\
\cline { 2 - 6 } Perlakuan & $\begin{array}{c}\text { Kada } \\
\mathrm{r} \text { air }\end{array}$ & $\begin{array}{c}\text { Protei } \\
\mathrm{n}\end{array}$ & $\begin{array}{c}\text { Lema } \\
\mathrm{k}\end{array}$ & $\begin{array}{c}\mathrm{Ab} \\
\mathrm{u}\end{array}$ & $\begin{array}{c}\text { Sera } \\
\mathrm{k} \\
\mathrm{kasa} \\
\mathrm{r}\end{array}$ \\
\hline Bagas raw & 2,45 & 1,97 & 0,39 & $\begin{array}{c}1,5 \\
5\end{array}$ & $\begin{array}{c}30,3 \\
4\end{array}$ \\
\hline $\begin{array}{l}\text { Bagas } \\
\text { terdelignifik } \\
\text { asi }\end{array}$ & $\begin{array}{c}10,6 \\
6\end{array}$ & 1,30 & 0,75 & $\begin{array}{c}2,3 \\
0\end{array}$ & $\begin{array}{c}27,3 \\
8\end{array}$ \\
\hline
\end{tabular}

Berdasarkan hasil pengujian Tabel 3, analisis proksimat bagas raw (sebelum di 
delignifikasi) menghasilkan total persentase bobot basah 36,7 \% (total persentase kadar air, protein, lemak, abu, dan serat kasar) dan menyisakan komponen karbohidrat (by difference) sebesar 63,3 $\%$. Analisis proksimat untuk bagas terdelignifikasi menghasilkan persentase bobot basah sebesar 42,39 \% dan menyisakan komponen karbohidrat sebesar 57,61\%. Penghitungan persentase kadar karbohidrat dapat dilihat pada Lampiran 1. Komponen karbohidrat terdiri atas komponen serat atau penyusun senyawa makromolekul. Oleh karena itu perlu diuji analisis kembali kandungan karbohidrat (Tabel 4). Menurut Fengel dan Wegener (1995), setiap komponen kimia kayu dapat dibedakan menjadi senyawa berberat molekul kecil yang terdiri atas bahan organik (ekstraktif) dan anorganik (abu), kemudian senyawa makromolekul yang terdiri atas polisakarida (selulosa, hemiselulosa) dan lignin.

Berdasarkan rumus penghitungan Van Soest et al. (1991), penurunan kadar komponen serat terjadi pada lignin sebesar $15,29 \%$ dan selulosa sebesar 25,5\%. Namun, peningkatan persentase terjadi pada hemiselulosa dari 11,54\% menjadi 23,97 \%. Nilai persentase komponen serat setelah degradasi merupakan selisih antara persentase setelah dan sebelum delignifikasi terhadap nilai mutlak bobot.

Penelitian serupa dilakukan oleh Lee (2003), delignifikasi bagas dengan $1 \% \mathrm{NaOCl}$ mengalami penurunan persentase lignin sebesar $6,9 \%$. Penurunan persentase lignin diikuti oleh penurunan selulosa sebesar $25,5 \%$, namun terjadi kenaikan persentase pada hemiselulosa. Hal tersebut terjadi karena dalam proses delignifikasi ada komponen polisakarida yang terlarut di dalam pelarut. Menjelang akhir delignifikasi dapat terjadi kehilangan polisakarida (Fengel dan Wegener 1995), sehingga mengurangi rendemen. Beg et al. (2001) menyatakan bahwa xilan atau hemiselulosa berada diantara lignin dan kumpulan serat selulosa, lapisan xilan berikatan secara kovalen dengan lignin dan non-kovalen dengan selulosa melalui ikatan hidrogen. Pelarut sodium hipoklorit dalam penelitian ini diduga mampu memutus ikatan kovalen dan melarutkan selulosa, sehingga terjadi penurunan.

Penurunan lignin, selulosa, BK, NDF, $\mathrm{ADF}$, protein, dan serat kasar akibat perlakuan delignifikasi mampu memutuskan ikatan-ikatan lignoselulosa dan lignohemiselulosa dengan efektif (Tabel 2 dan 3). Fengel dan Wegener (1995) pengaruh hidrolitik yang menyebabkan pemecahan rantai polisakarida. Ghunu dan Tarmidi (2006) menyatakan bahwa akibat pemecahan polisakarida secara enzimatis maupun proses kimiawi yang semakin lama mengakibatkan degradasi NDF semakin bertambah banyak. Pada penelitian Ghunu dan Tarmidi (2006) menyatakan bahwa hasil penurunan kandungan NDF, ADF, dan lignin pada substrat rumput kering (Kume) terbaik ialah berdasarkan peningkatan kadar air substrat tertinggi yaitu 77,5\%. Penurunan serupa terjadi pada protein sebesar $0,67 \%$ merupakan protein terdegradasi selama proses delignifikasi. Fengel dan Wegener (1995) sel parenkim dalam bagian batang bukan kayu mengandung protein sekitar $1 \%$, yaitu pada kambium dan bagian kulit terdalam. Protein tergolong senyawa ekstraktif pada bagas.

Hasil analisis sampel bebas air sering ditemukan perubahan berat kering karena melalui proses pengeringan dan karena kesukaran penimbangan sampel kering tanpa penyerapan uap air. Penurunan tersebut juga bisa disebabkan oleh konsentrasi pelarut delignifikasi yang digunakan. Hasil penelitian Lee (2003), pada konsentrasi $\mathrm{NaOCl} 1 \%$ terjadi kehilangan berat lebih sedikit yaitu 6,9\% dibandingkan konsentrasi $\mathrm{NaOCl} 5 \%$ yaitu sebesar $51 \%$. Hubungan antara penurunan berat kering dengan konsentrasi pelarut dalam delignifikasi dikaitkan dengan ikatan komplek lignin-polisakarida, jika konsentrasi yang digunakan tinggi maka dapat terjadi kehilangan banyak polisakarida.

Penurunan persentase yang terjadi dalam protein berbanding terbalik dengan persentase lemak, terjadi peningkatan sebesar 0,36\%. Lemak dan atau minyak (gliserol) dalam kayu terdapat dalam bentuk asam asetat yang berikatan dengan polisakarida sebagai ester, akibat dari proses delignifikasi beberapa ikatan tersebut putus dan membentuk senyawa lemak tunggal. Komponen abu sebesar 1,55\% lebih besar dibandingkan jenis kayu daerah beriklim sedang berkisar antara 0,2 dan $0,5 \%$, nilai tersebut bisa lebih besar jika berasal dari tanaman tebu bukan limbah ampas tebu. Fengel dan Wegener (1995) dijelaskan bahwa kesalahan menentukan kandungan abu kemungkinan disebabkan hilangnya sejumlah garam amonia dan logam klorida atau juga disebabkan kurang efisiennya oksidasi terhadap karbonat-karbonat dari logam-logam alkali. Peningkatan persentase yang terjadi berarti prosedur tidak mengalami kesalahan analisis, karena tidak terjadi pengurangan jumlah garam dan logam. Persentase penurunan serat kasar akan 
berbdaning lurus dengan NDF dan ADF, jadi serat kasar juga dipengaruhi oleh kadar air suatu bahan.

Hasil analisis proksimat dan komponen serat bagas sebelum dan sesudah (Tabel 2 dan 3) berbeda dengan hasil analisis proksimat oleh Sandra et al. (2007) yang menyatakan bahwa bagas (raw) mengandung selulosa 37,35\%, hemiselulosa $23,66 \%$, lignin $25,10 \%$, senyawa ekstraktif lain 3,25\%, dan senyawa abu 1,79\%, perbedaan tersebut dipengaruhi beberapa faktor seperti perbedaan varietas tebu dan pengaruh pengambilan sampel acak di berbeda tempat. Faktor yang mempengaruhi tersebut tidak dapat dikontrol dan diseragamkan dikarenakan bahan dasar merupakan jenis limbah. Menurut Sun dan Cheng (2002), bahwa kandungan bagas sebagai bahan lignoselulosa jenis kayu lunak yang secara umum diketahui sebagai sisa hasil pertanian dan limbah mengandung selulosa (40-50 \%), hemiselulosa $(25-35 \%)$, dan lignin $(25-35 \%)$.

Selain ketersediaannya yang melimpah bahan lignoselulosa juga tidak bersaing dengan bahan dasar pangan. Beberapa contoh bahan lignoselulosa yang dapat digunakan antara lain limbah pertanian (rumput, alang-alang, sekam padi, jerami, batang gandum, tongkol jagung) dan limbah hasil samping industri fermentasi (molase, bagas) (Iranmahboob et al. 2002). Menurut Lavarack et al. (2002) bagas merupakan hasil samping proses pembuatan gula tebu (sugarcane) yang mengandung residu berupa serat. Komponen kimia dari serat bagas secara rinci meliputi 37,35 $\%$ glukan (selulosa), 23,66\% xilan (hemiselulosa), 2,1\% lignin, 3,25\% senyawa ekstraktif lain, dan $1,79 \%$ senyawa abu (Sandra et al. 2007). Sedikitnya $50 \%$ serat bagas diperlukan sebagai bahan bakar (ketel) sedangkan 50\% sisanya hanya ditimbun sebagai buangan yang memiliki nilai ekonomi rendah.

Proses pretreatment pada penelitian ini bertujuan untuk mempermudah proses hidrolisis menggunakan enzim pada tahap penelitian selanjutnya. Hasil analisis proksimat bagas berbeda dengan hasil analisis proksimat oleh Sandra et al. (2007). Perbedaan tersebut dipengaruhi beberapa faktor seperti perbedaan varietas tebu dan pengaruh pengambilan sampel acak di tempat yang berbeda. Faktor yang mempengaruhi tersebut tidak dapat dikontrol dan diseragamkan.

Biomassa yang tidak dipretreatmen akan bersifat recalcitrant bagi mikroba, karena kandungan lignin yang akan menghambat penetrasi enzim (Himmel 2008). Dalam penelitian ini pretreatmen bagas bertujuan untuk mendapatkan ekstraksi produk polisakarida xilan yang terkandung di dalamnya. Xilan yang dihasilkan nantinya dapat digunakan sebagai substrat dalam reaksi enzim, dan produk yang diperoleh adalah monosakarida yang dapat digunakan sebagai bahan fermentasi untuk bioetanol, probiotik, prebiotik, dan lain sebagainya. Oleh karena itu pretreatment sangat penting karena berpengaruh dengan proses enzimatik selanjutnya. Pretreatment akan merusak dinding sel tanaman dan akan mempermudah akses enzim pada polisakarida tanaman.

Apabila penelitian ini dapat diaplikasikasikan setiap pabrik gula artinya industri tersebut behasil menerapkan sistem ekoindustri, yang berarti dapat memproduksi dengan lebih bersih. Manfaat lain selain meminimalisir dampak pencemaran lingkungan, pabrik gula juga dapat mendapatkan profit dari hasil teknologi ini. Hasil teknologi ini tentunya bernilai jual yang tinggi, karena dibutuhkan oleh perusahaan-perusahaan yang memproduksi bioetanol baik swasta maupun BUMN. Selain itu polisakarida hasil dari pretreatmen ini dapat digunakan dalam perusahaan pakan ternak untuk memproduksi produk tambahan berupa prebiotik maupun probiotik.

\section{KESIMPULAN DAN SARAN}

Sebanyak $50 \%$ limbah bagas sisa dari ketel untuk pemanasan dapat diolah menjadi polisakarida yaitu xilan dan dapat dimanfaatkan untuk bahan dasar bioetanol, produksi enzim xilanase, prebiotik maupun probiotik. Xilan dapat dijual ke industri lain atau diolah sendiri sampai menjadi produk siap pakai. Hasil ekstraksi xilan bagas diperoleh 9,9\% xilan dari bagas dan setelah pemurnian diperoleh 3,4 \% xilan larut. Setiap melalui tahapan pretreatmen terjadi pengurangan berat bagas dari $1000 \mathrm{~g}$ menjadi $34 \mathrm{~g}$ pada akhir pemurnian xilan. Rendemen bagas hasil delignifikasi sebanyak 704,74 g (29,74 \%), dengan rendemen ekstraksi sebanyak 98,80 g xilan $(9,9 \%)$ dan setelah purifikasi didapatkan $3,4 \%$ xilan murni. Perolehan xilan dapat dimaksimalkan lagi melalui penelitian untuk mengetahui efektivitas konsentrasi senyawa kimia yang ditambahkan dan waktu inkubasi yang ditambahkan. Hal tersebut bertujuan untuk mendapatkan efisiensi dalam perolehan yield xilan. 


\section{DAFTAR PUSTAKA}

Beg, QK., M. Kapoor, L. Mahajan, and GS. Hoondal, 2001, Microbial xylanases and their industrial applications: a review, Appl Microbiol Biotechnol. 56:326-338.

Campo DI, Alegria I, Zazpe M, Echeverria M, and Echeverria I, 2006, Diluted acid hydrolysis pretreatment of agri-food wastes for bioethanol production, Industr Crops Products. 24: 214-221.

Cross CF, Bevan EJ. 1912. Researches on cellulose. Vol III. London (GB): Longmans, Green, Co.

Fengel, D. and G. Wegener, 1995, Wood Chemistry, Ultrastructure, Reacions. Walter de gruyter and Co, Berlin.

Ghunu S, and Tarmidi AR, 2006, The Change of Fiber Components of Pleurotus ostreatus-Bioconverted "Kume " Grass (Sorghum plumosum var. Timorense) Caused by Different Substrate Moisture Content dan Inoculant Doses), J Ilmu Ternak. 6(2):81-86.

Himmel, ME, 2008, Biomass recalcitrance; deconstructiing the plant cell wall for bioenergy, Blackwell Publishing. Singapore.

Iranmahboob, J., F. Nadim, and S. Monemi, 2002, Optimizing acid-hydrlysis: a critical step for production of ethanol from mixed wood chips, Biomass and Bioenergy. 22: 401-404.

Lavarack, BP., GJ. Griffin, and D. Rodman, 2002, The acid hydrolysis of sugarcane bagas hemicellulose to produce xylose, arabinose, glucose \& other products, Biomass Bioenergy. 23:367-380.

Lee YJ. 2003, Oxidation of sugarcane bagas using a combination of hypochlorite and peroxide [Thesis], Korea (KR): Submitted to The Graduate Faculty of theLouisiana State University dan Agricultural dan Mechanical College.

Richana N, Lestina P, dan Irawadi TT, 1994, Karakterisasi lignoselulosa dari limbah tanaman pangan dan pemanfaatannya untuk pertumbuhan bakteri RXA III penghasil xilanase, J Penel Pertan Tan Pang. 23(3):171-176.
Richana, N, 2002, Produksi dan prospek enzim xilanase dalam pengembangan bioindustri di Indonesia, Buletin AgroBio. 1:29-36.

Richana, N., TT. Irawadi, MANur, MA., Sailah, I., Syamsu, K., and Arkenan, Y., 2007, Ekstraksi xilan dari tongkol jagung. $J$. Pascapanen. 4(1):38-43.

Samsuri, M., M. Gozan, A. Wijanarko, H. Hermansyah, PPDK. Wulan, S. Dianur, M. Nasikin, and B. Prasetya, 2009, Hydrolysys of bagas by cellulase and xylanase for bioethanol production in simultaneous saccharification \& fermentation, Journal of Applied and Industrial Biotechnology. 2(2):19799784.

Sandra, GMR., AR. Rafael, SG. Carlos, CC. Alin, and R. Filho, 2007, Pretreatment of sugarcane bagas with phosphoric and sulfuric diluted acid for fermentable sugars production by enzymatic hydrolysis, School of Chemical Engineering, UNICAMP, Brazil.

SunY, and ChengJ, 2002, Hydrolysis of lignocellulosic materials for ethanol production: a review. Biores Technol.83:1-11.

Van Soest PJ, Robertson JB, and Lewis BA, 1991, Methods for dietary fiber, neutral detergent fiber, and nonstrach polysaccharides in relation to animal nutriion, J Dairy Sci. 74:3583-3597. 